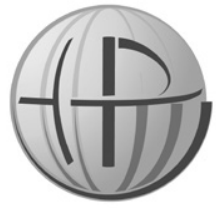

Horyzonty Polityki 2020, Vol. 11, No 36

\section{Ewa Bujwid-KureK}

http://orcid.org/0000-0001-7634-828X Uniwersytet Jagielloński w Krakowie Wydział Studiów Międzynarodowych i Politycznych ewa.bujwid-kurek@uj.edu.pl

DOI: 10.35765/HP.1959

\title{
Pandemicznie doświadczony świat COVID-19 - reakcja rządów państw pojugosłowiańskich. Casus stanu wyjątkowego w zarysie refleksji politologicznej
}

Jeśli nie nauczymy się samodyscypliny i nie stawimy czoła problemom, które w większości sami prowokujemy, wówczas zostaną one rozwiązane, przynajmniej czasowo, za nas, i to w zdecydowanie gorszy sposób

(Cartwright, Biddiss, 2002, s. 241)

\section{Streszczenie}

CEL NAUKOWY: Naczelnym celem badawczym niniejszych rozważań jest ustalenie, w których z państw pojugosłowiańskich w obliczu śmiercionośnej pandemii COVID-19 zdecydowano się na ogłoszenie stanu wyjątkowego.

PROBLEM I METODY B ADAWCZE: Stan wyjątkowy ma chronić: bezpieczeństwo obywateli, ustrój państwa, porządek publiczny. W okresie stanu wyjątkowego zmieniają się proporcje między prawami człowieka a uprawnieniami państwa - na korzyść władz państwowych. W obliczy pandemii COVID-19 nie wszystkie rządy państw pojugosłowiańskich ogłosiły stan wyjątkowy. Zrobiły to: Serbia, Bośnia i Hercegowina, Macedonia Północna oraz Kosowo. W przypadku każdego z wymienionych państw ogłoszenie stanu wyjątkowego wiązało się ze sporami politycznymi, dzieląc zarówno gremia polityków, jak i społeczeństwo. Spór toczył się głównie wokół przesunięcia terminu wyborów parlamentarnych. Artykuł powstał przy wykorzystaniu 
metod badawczych właściwych dla dyscypliny nauki o polityce i administracji: case stady (wąskie ujęcie), analizy źródeł pierwotnych i metody komparatystycznej.

PROCES WYWODU: Artykuł składa się z wprowadzenia, w którym uzasadniono wybór tematu badawczego i ustalono istotę stanu wyjątkowego. W czterech kolejnych punktach zwrócona została uwaga na reakcję na COVID-19 tylko tych państwa pojugosłowiańskich (Serbię, Bośnię i Hercegowinę, Macedonię Północną, Kosowo), w których ogłoszono stan wyjątkowy. W rekapitulacji dokonano podsumowania, akcentując konflikty, które wynikły z ogłoszenia stanu wyjątkowego w państwach poddanych analizie.

WYNIKI ANALIZY NAUKOWEJ: Tylko w czterech spośród siedmiu państw pojugosłowiańskich ogłoszony został stany wyjątkowy. W Serbii, Macedonii Północnej i Kosowie przesunięte zostały wyznaczone kalendarzem wyborczym wybory parlamentarne, w przypadku każdego z tych państw wywołało to ostre spory polityczne, a w Macedonii Północnej wzbudzona na tym tle eskalacja konfliktu spowodowała dymisję rządu.

WNIOSKI, INNOWACJE, REKOMENDACJE: Omawiana problematyka jest innowacyjna, jak dotąd nie została przedstawiona w politologicznej literaturze przedmiotu. Intrygującym pozostaje pytanie, dlaczego nie wszystkie rządy państw (nie tylko pojugosłowiańskich) w obliczu tak groźnej dla zdrowia i życia ludzkiego pandemii, jaką jest COVID-19, nie zdecydowały się na ogłoszenie stanu wyjątkowego, który nadrzędne akty prawne (konstytucja) zwykły gwarantować.

\section{KeYwORDS:}

pandemia, COVID-19, stan wyjątkowy, Serbia, Bośnia i Hercegowina, Macedonia Północna, Kosowo

\section{Abstract}

THE PANDEMIC WORLD OF COVID-19THE REACTION OF THE YUGOSLAV AUTHORITIES. THE CASE OF THE STATE OF EXCEPTION IN THE CONTEXT OF POLITICAL REFLECTION

SCIENTIFIC OBJECTIVE: The main research goal of these considerations is to determine in which of the Post Yugoslav countries it was decided to declare a state of emergency during time of deadly COVID-19 pandemic. 
PROBLEM AND RESEARCH METHODS: The state of emergency is created to protect: the security of citizens, the state system, public order. During the state of emergency, the proportions between human rights and the powers of the state change - in favour of state authorities. In the face of the COVID-19 pandemic, not all Post Yugoslav governments have declared a state of emergency. The following countries did so: Serbia, Bosnia and Herzegovina, Northern Macedonia and Kosovo. In each of these countries, the declaration of a state of emergency was associated with political disputes.

THE PROCESS OF ARGUMENTATION: The article consists of an introduction in which the choice of the research topic was justified and the essence of the state of emergency was established. In the next four points, attention was drawn to the response to COVID-19 only to those Yugoslavian states (Serbia, Bosnia and Herzegovina, Northern Macedonia, Kosovo) in which a state of emergency was declared.

RESEARCH RESULTS: Only in four out of seven Yugoslavian states the state of emergency was declared. In case of Serbia, Northern Macedonia and Kosovo, scheduled parliamentary election was postponed, for each of the countries it caused sharp political disputes, and in the case of Northern Macedonia the escalation of the conflict caused the resignation of the government.

CONCLUSIONS, INNOVATIONS, AND RECOMMENDATIONS: The issues discussed are innovative, so far not discussed in the political literature. The question that remains intriguing is why not all governments in case of such a dangerous pandemic for human health and life as COVID-19 have not decided to declare a state of emergency.

\section{KeYwORDS:}

Pandemic, COVID-19, state of emergency, Serbia, Bosna and Herzegovina, Northern Macedonia, Kosovo

\section{WPROWADZENIE}

Przedwiośnie roku 2020 zapamiętane zostanie jako okres rozprzestrzeniającej się z niebywałą prędkościa, pochłaniającą setki ofiar ludzkich na całym świecie, pandemią SARS (Severe Acute Respiratory Syndrome) - COVID-19, którą Światowa Organizacja Zdrowia (WHO) uznała za pandemię wywołaną wirusem SARS-CoV-2. W dziejach ludzkości pandemie nie są niczym nowym, by przypomnieć wyniszczającą w latach 1348-1361 dżumę (nieco później określanej mianem 
czarnej śmierci) (Cartwright, Biddiss, 2002, Kiple, 2002, passim), pod koniec XV wieku syfilis, w 1812 roku tyfus (gorączka więzienna), cholera (azjatycka), gruźlica, ospa czy AIDS (Acquired Immune Deficiency Syndrom $)^{1}$ etc.

(...) epidemia rozpoczęła się $\mathrm{w}$ momencie, gdy, szczególnie w świecie rozwiniętym, święcono zwycięstwo na polu zwalczania zakaźnych chorób epidemicznych (...) Stąd AIDS pojawił się w takim momencie historycznym, kiedy niewielkie było społeczne i polityczne doświadczenie w zarządzaniu kryzysem na polu zdrowia publicznego o takich rozmiarach (Cartwright, Biddiss, 2002, s. 233).

Od czasu grypy hiszpanki lat 1918-1920, która pochłonęła $50 \mathrm{mln}$ ofiar śmiertelnych, nie było żadnej podobnej epidemii o równej sile rażenia jak AIDS. W roku 2003 pojawiło się śmiertelne zapalenie płuc (SARS), które wywołało co najmniej 800 tysięcy zachorowań, z czego $10 \%$ okazało się śmiertelnych (Brown, 2018, s. 17). SARS po raz pierwszy wystąpiło w Chinach, niestety władze owładnięte obsesją tajności, co charakterystyczne dla chińskiego reżimu politycznego, nie poinformowały o tej groźnej chorobie $\mathrm{WHO}^{2}$. Świńska grypa zidentyfikowana jako H1N1, wybuchła w 2009 roku w USA, do czerwca tego roku odnotowanych zostało 30 tys. zachorowań. W obliczu takiej sytuacji WHO ogłosiło zagrożenie pandemią ${ }^{3}$ (Brown, 2018, s. 165) w 74 krajach. Nieco później pojawił się MERS, bliskowschodni zespół niewydolności oddechowej, którym w latach 2012-2015 zaraziło się 1400 osób $^{4}$. Chorobami nierespektującymi żadnych granic były też: Ebola (gorączka krwotoczna) i Zika. 17 listopada 2019 roku w Chinach (środkowa część) w mieście Wuhan (prowincja Hubei) odnotowany został pierwszy przypadek zachorowania na

1 Zespół nabytego braku odporności.

2 W 28 krajach choroba ta pochłonęła 800 śmiertelnych istot ludzkich. Ibidem, s. 237.

3 Zob. też: M. Chan, World Now at the Start of 2009 Influenza Pandemic, World Health Organization [on line:] http://www.who.int/mediacentre/news/statements/2009/h1n1_pandemic_phase6_20090611/en/(dostęp: 11.06.2020).

$4 \quad$ Ibidem, s. 17. Zob. też: World Health Organization, Middle East Respiratory Syndrome Coronavirus (MERS-CoV). Summary of Current Situation, Literature Upade and Risk Assessment, 7 lipca 2015 [on line] http://apps.who.int.iris.bitstream/10665/179184/WHO_MERS_RA_15.1_eng.pdf. (dostęp: 10.06.2020). 
COVID-19, z którym do chwili obecnej, z różnym powodzeniem, zmierzają się rządy państw na całym świecie, walcząc z niezwykle niebezpiecznym, śmiercionośnym wirusem. 11 marca 2020 roku choroba ta uznana została przez WHO za pandemię ${ }^{5}$. Walka $\mathrm{z}$ tą nową pandemią - COVID-19 - może być bardzo trudna, zważywszy na problemy w przypadku występowania grypy. I choć od blisko stu lat wiedza o grypie znacznie się pogłębiła, to jednak jak dotąd wciąż jeszcze nie opracowano skutecznego leku ani zapobiegającego, ani też leczącego tę niebezpieczną dla zdrowia ludzkiego chorobę. Pamiętajmy, że grypa uznana została za „wroga numer jeden ludzkości” ze względu na jej stopień zakażeń i skutków, które niesie ze sobą (Brown, 2018).

Stojące w obliczu pandemii COVID-19 rządy niemal wszystkich państw na świecie zmagają się z wieloma problemami, wśród których kluczowe jest zagwarantowanie bezpieczeństwa ludności. W celu sprostania zadaniu sięgają one po różne mechanizmy zarządzania kryzysowego. Niejednokrotnie na obszarze całego państwa ogłaszany jest, zazwyczaj konstytucyjnie gwarantowany, jeden ze stanów nadzwyczajnych - stan wyjątkowy. Nie wszystkie jednak państwa, zmagając się z tą epidemią, decydują się na ogłoszenie takiego stanu.

$Z$ racji zainteresowań badawczych autorki, szczególna uwaga zostanie nakierowana na państwa pojugosłowiańskie. Za główny cel badawczy przyjęto próbę odpowiedzi na pytania - jak w obliczu COVID-19 zareagowały rządy państw tego regionu (Słowenii, Chorwacji, Macedonii Północnej, Bośni i Hercegowiny, Serbii, Czarnogóry, Kosowa) oraz które z nich sięgnęły po odpowiedni instrument konstytucyjny, tzn. ogłoszono tam stan wyjątkowy. Na chwilę obecną (lipiec 2020 r.) spośród wyżej wymienionych państw rządy tylko czterech z nich ogłosiły stan wyjątkowy. Z takiego prawa skorzystał rząd Serbii, Bośni i Hercegowiny, Macedonii Północnej, Kosowa ${ }^{6}$. Natomiast rządy Chorwacji, Słowenii, Czarnogóry nie sięgnęły po takie rozwiązanie. W niniejszym artykule zwrócona zostanie uwaga

5 Pandemia to epidemia danej choroby, która w tym samym czasie obejmuje bardzo rozległe obszary kraju, kontynentu i cały świat.

6 Koronawirus: Które kraje wprowadzity stan wyjatkowy w Europie? [on line:] https://www.euractiv.pl/section/bezpieczenstwo-i-obrona/news/koronawirus-ktore-kraje-wprowadzily-stan-wyjatkowy/(dostęp: 01.07.2020). 
tylko na te państwa, które - zmagając się z COVID-19 - ogłosiły stan wyjątkowy.

Z perspektywy politologicznej warto zauważyć, że stan wyjątkowy to obok stanu wojennego i stanu klęski żywiołowej jeden $z$ trzech konstytucyjnych stanów nadzwyczajnych, który może pociągać za sobą określone skutki, np. (w zależności od stopnia zagrożenia) ograniczenia wolności i praw człowieka i obywatela. Stan wyjątkowy wprowadza się wtedy, gdy sytuacja w państwie jest na tyle poważna, że środki przewidziane w konstytucji nie są wystarczające. Wprowadzenie stanu wyjątkowego zmusza rządy państw do działań mających na celu jak najszybsze przywrócenie dotychczasowego funkcjonowania kraju. Stan wyjątkowy ma chronić po pierwsze bezpieczeństwo obywateli, po drugie - ustrój państwa i po trzecie - porządek publiczny. W okresie stanu wyjątkowego zmieniają się proporcje między prawami człowieka a uprawnieniami państwa - na korzyść władz państwowych. Dlatego tak ważne jest, by ustawy zasadnicze w sposób szczegółowy i precyzyjny regulowały ich specyfikę (Leszczyński, 2011). Pamiętajmy, że zważywszy na niebezpieczeństwo zakłócenia funkcjonowania państwa stany nadzwyczajne, zwane też niekiedy stanami kryzysowymi, zwykle stosuje się w szczególnych sytuacjach zagrożenia dla niepodległości państwa, spokoju i bezpieczeństwa wewnętrznego, instytucji demokratycznych lub ładu ekonomicznego (Kalina-Prasznic, 1997, s. 309, Bujwid-Kurek, 2012, s. 190 i Bujwid-Kurek, 2012, s. 111-127). Stany nadzwyczajne w doktrynie prawa konstytucyjnego określa się mianem stanów szczególnego zagrożenia państwa (Skrzydło, 2002, s. 308, Bujwid-Kurek, 2012, s. 190). Wskazanie na określone stany wymaga jednak podjęcia konkretnych działań, wśród których najważniejszymi są m.in.: określenie podstaw prawnych nadzwyczajnych uprawnień, wskazanie organów korzystających z tych uprawnień, uregulowanie problemu kontroli decyzji wprowadzenia tych stanów, ustalenia katalogu środków prawnych wchodzących w zakres tych uprawnień, uregulowanie kwestii kontroli stosowania nadzwyczajnych uprawnień, sprecyzowania kwestii odpowiedzialności organów państwowych korzystających z tych uprawnień (Skrzydło 2002, s. 303, Chmaj, Sokól, 2001, s. 355). Ogłoszenie stanu wyjątkowego nie jest dyskrecjonalną decyzją właściwych organów państwa - zazwyczaj jest skutkiem zaistnienia ściśle określonej sytuacji. 
Niewątpliwie wprowadzenie stanu wyjątkowego wymusza na organach władzy publicznej określone funkcjonowanie, a już na pewno ma wpływ na zakres stosownych wolności praw jednostki. Istnieje utrwalona bardzo często stosowana zasada - działania podejmowane przez władze po wprowadzeniu stanu wyjątkowego muszą być adekwatne do stopnia zagrożenia, a ich celem jest to, by w jak najkrótszym czasie zostało przywrócone normalne funkcjonowanie państwa.

Podjęty temat ma charakter pionierski, $\mathrm{w}$ opinii autorki $\mathrm{w}$ pełni zasługujący na refleksję politologiczną. Eksplikowany problem badawczy, jak dotąd jeszcze nie został poddany naukowej eksploracji $\mathrm{w}$ tym zakresie, zatem wypełnia lukę $\mathrm{w}$ prezentowanej tematyce. Omawiana problematyka jest na tyle nowa, że nie doczekała się jeszcze naukowych opracowań zwartych (monografii), stąd też prezentowany artykuł (szczególnie jego część zasadnicza) został napisany głównie na podstawie zasobów netograficznych.

\section{STAN WYJĄTKOWY W REPUBLICE SERBII - REAKCJA NA COVID-19}

Kiedy 6 marca 2020 roku zostały potwierdzone pierwsze przypadki zachorowania na SARS-CoV2, rząd Republiki Serbii, jako jeden z pierwszych na świecie, podjął natychmiast niezbędne działania prewencyjne i ochronne. 15 marca tego roku decyzją Narodnej Skupštiny Republiki Serbii (Zgromadzenie Narodowe - parlament) został ogłoszony stan wyjątkowy. Wprowadzenie tego stanu wpłynęło na funkcjonowanie państwa i społeczeństwa (Bujwid-Kurek, 2012, s. 191). W kwestii stanu wyjątkowego stanowi Konstytucja Republiki Serbii z 2006 roku w art. 200:

Stan wyjątkowy

Artykuł 200

W sytuacji zagrożenia porządku publicznego państwa lub obywateli Zgromadzenie Narodowe ogłasza stan wyjątkowy $(\ldots)^{7}$.

$7 \quad$ Konstytucja Republiki Serbii, tłumaczenie z języka serbskiego i wstęp Ewa Bujwid-Kurek, Warszawa 2018, s. 200 i 201. Zob. też: Što po Ustavu Srbije podrozumeva uvođenje vanrednog stanja? [on line:] https://www.danas.rs/drustvo/ 
Prezydent Republiki Serbii Aleksandr Vučić, ogłaszając stan wyjątkowy na obszarze całego kraju, oznajmił że postępuje zgodnie z przepisami, na które pozwalają mu kompetencje, wynikające z pełnionej funkcji głowy państwa. Korzystając z tych uprawnień zapowiedział też, że rząd bardzo szybko wprowadzi „,najostrzejsze środki zaradcze, mające ograniczać skalę epidemii" ${ }^{8}$. Wtedy też, mając na uwadze zaplanowane wybory parlamentarne, Państwowa Komisja Wyborcza Serbii wydała oświadczenie informujące o tym, że w związku z pandemią COVID19 i ogłoszeniem stanu wyjątkowego w kraju wybory parlamentarne, które miały się odbyć 26 kwietnia 2020 roku, zostają przełożone na czas późniejszy: „Wszystkie terminy związane z procesem wyborczym zostaną ustalone po zakończeniu stany wyjątkowego" ${ }^{\prime}$.

O przesunięciu terminu wyborów poinformował także prezydent Republiki Serbii Aleksandar Vučić (lider Serbskiej Partii Postępowej). Wybory parlamentarne w Serbii wedle kalendarza wyborczego miały się odbyć 26 kwietnia 2020 roku $^{10}$, jednak w związku z ogłoszeniem stanu wyjątkowego zostały przesunięte na 21 czerwca, tegoż roku, a kampania wyborcza była możliwa do wznowienia od 7 maja 2020 roku. W momencie podjęcia tych decyzji (o stanie wyjątkowym i przesunięciu terminu wyborów parlamentarnych) w Serbii potwierdzonych było zaledwie 55 przypadków zakażenia koronawirusem. Uznano jednak, mając na uwadze doświadczenia płynące $z$ innych państw, że pandemia szybko nie minie i uniemożliwi bezpieczne przeprowadzenie wyborów parlamentarnych. Stąd też kadencja parlamentu została przedłużona ${ }^{11}$. Nowy termin wyborów spotkał

sta-po-ustavu-srbije-podrazumeva-uvodjenje-vanrednog-stanja/ (dostęp: 04.07.2020).

$8 \quad$ Korona virus $i$ vanredno stanje u Srbiji: Šta to znači i koje mere su uvedene [on line:] https://www.bbc.com/serbian/lat/srbija-51905122 (dostęp: 02.07.2020).

9 Ibidem.

10 Serbia wprowadza stan wyjatkowy w zwiazku z pandemia [on line:] https://www. defence24.pl/serbia-wprowadza-stan-wyjatkowy-w-zwiazku-z-epidemia-koronawirusa (dostęp: 01.07.2020).

11 Wybory prezydenckie 2020. Na świecie przenosi się wybory, ale nie wszędzie [on line:] https://wiadomosci.onet.pl/swiat/wybory-prezydenckie-2020-na-swiecie-przenosi-sie-wybory-ale-nie-wszedzie/66w5cgw (dostęp: 03.07.2020). Zob. też: Izbori u Srbiji 2020, Kosovo, korona i UE: šta sve čeka novu 
się z niezadowoleniem zarówno wśród ugrupowań opozycyjnych ${ }^{12}$, jak i u obywateli. Na ostry sprzeciw opozycji zareagowała premier rządu Republiki Serbii Ana Brnabić, która tuż przed głosowaniem w Parlamencie w sprawie zniesienia stanu wyjątkowego wyraziła opinię, że kluczowe jest, aby wybory tak czy inaczej przeprowadzić, jednocześnie odniosła się do przykładów innych państw, takich jak np. Francja, Korea Południowa, Bawaria w Niemczech, w których z sukcesem przeprowadzone zostały wybory ${ }^{13}$.

Zdaniem prezydenta A. Vučicia istniało przekonanie, że sytuacja po zniesieniu stanu wyjątkowego (obejmującego zamknięcie granic i lotnisk, godzinę policyjną i zakaz poruszania się, blokady weekendowe) powinna być systematycznie i konsekwentnie kontrolowana przez rząd i parlament ${ }^{14}$. Po niemal dwóch miesiącach ograniczonych swobód obywatelskich, co dopuszcza Konstytucja Republiki

Vladu i parlament [on line:] https://www.bbc.com/serbian/lat/srbija-53095067 (dostęp: 04.07.2020).

12 Niespokojna sytuacja polityczna w Serbii trwa niemal nieprzerwanie od 2017 r., kiedy funkcję prezydenta RS objął Aleksandar Vučić. Liczne demonstracje uważane są za największe w Serbii od obalenia rządów Slobodana Miloševicia. Tym razem odbył się w Belgradzie protest zorganizowany przez ruch „Svetlo" (Światło), którego głównym postulatem był zmiana terminu głosowania. Protestujący domagali się utworzenia także nowego tymczasowego rządu technicznego na okres od 6 do 12 miesięcy, co dawałoby gwarancję równych szans i warunki uczestnictwa w wyborach wszystkim zainteresowanym wyborami kandydatom. Protest w Belgradzie nie był jedynym tego typu incydentem, zob. Protest sa zahtevom odlaganja izbora, kolona demonstranata ispred RTS [on line:] http://rs.n1info.com/Vesti/a597737/ Protest-protiv-vlasti-na-Trgu-Republike.html (dostęp: 01.07.2020). Niezadowoleniu z obecnej władzy dają wyraz także mieszkańcy innych miast Serbii - każdego dnia o godz. 20.00 biorą oni udział w akcji „Bukom protiv diktature" Hałas przeciwko dyktaturze), hałasem, głośną muzyką protestują przeciwko działaniom podejmowanym w walce z koronawirusem, zob. Akcija "Bukom protiv diktature" i 13. Veče zaredom u više gradova u Srbije [on line:] http://rs.n1info.com/Vesti/a597535/Akcija-Bukom-protiv-diktature-i-13.-vece-zaredom-u-vise-gradova-u-Srbiji.html (dostęp: 01.07.2020).

13 Brnabić, A. S izborima nema licitirnja, moramo da vratimo mandate građani$m a$ [on line:] http://rs.n1info.com/Izbori-2020/a596755/Brnabic-S-izborima-nema-licitiranja-moramo-da-vratimo-mandate-gradjanima.html (dostęp: 02.07.2020).

14 Prezydent Serbii zapowiada odwołanie stanu wyjatkowego [on line: ]https://www. tvp.info/47863787/prezydent-serbii-zapowiada-odwolanie-stanu-wyjatkowego (dostęp: 01.07.2020). 
Serbii ${ }^{15}$, i paraliżu życia, Narodna Skupština podjęła decyzję o zniesieniu stanu wyjątkowego z dniem 7 maja 2020 roku, pozostawiając $w$ mocy takie obostrzenia, jak m.in.: zachowanie dystansu społecznego i obowiązek noszenia maseczek w miejscach publicznych ${ }^{16}$. Wybory parlamentarne wyznaczono na 21 czerwca. W tym samym dniu miały się też odbyć (wg kalendarza wyborczego) wybory samorządowe w Serbii ${ }^{17}$. Tak więc groźna dla życia ludzkiego pandemia, która wciąż była obecna, ostatecznie nie wstrzymała „,życia politycznego" i nie stanęła na przeszkodzie w organizowaniu wyborów powszechnych (parlamentarnych i samorządowych).

\section{STAN WYJĄTKOWY W BOŚNI I HERCEGOWINIE REAKCJA NA COVID-19}

Treść konstytucji Bośni i Hercegowiny została uzgodniona jako aneks IV do układu pokojowego z Dayton z 21 listopada 1995 roku. Podpisano ją 14 grudnia tego samego roku w Paryżu wraz z ww. układem (The General Framework Agreement for Peace in Bosnia and Herzegovina), kończącym wojnę w Bośni i Hercegowinie (1992-1995). Konstytucja Bośni i Hercegowiny nie zawiera regulacji dotyczących stanów nadzwyczajnych, w żadnym miejscu nie widnieje literalny artykuł temu poświęcony. Natomiast $\mathrm{w}$ jej zapisie ustala się między innymi tryb uchwalania ustaw dotyczących obronności i bezpieczeństwa

15 Stan wyjątkowy w Serbii dopuszcza ograniczenie: praw i swobód obywatelskich, swobodę poruszania się, tajność korespondencji, ochronę danych osobowych, wolność, mediów, wolność zrzeszania się i inne prawa zagwarantowane w Konstytucji Republiki Serbii z 2006 r. Szeroki wachlarz ograniczeń zob. Korona virus i vanredno stanje u Srbiji, dz. cyt., s. 3 i 4 z 12.

$16 U$ Srbiji je jutros završen poslednij policijski čas: poštujte mere koje su i dalje na snazi [on line:] https://www.telegraf.rs/vesti/srbija/3186771-u-srbiji-je-jutros-zavrsen-poslednji-policijski-cas-pos (dostęp: 01.07.2020).

17 Historyczne spory stana na drodze Macedonii Płn. do UE? [on line:] https:// www.euractiv.pl/section/polityka-wewnetrzna-ue/news/unia-europejska-bulgaria-macedonia-polnocna-rozmowy-akcesyjne-koronawirus-kryzys/ (dostęp: 03.07.2020). 
państwa ${ }^{18}$. O ile Konstytucja, o której mowa, nie stanowi expressis verbis w kwestii nas interesującej, to jednak w Konstytucji Republiki Serbskiej (część składowa - entitet $\mathrm{BiH}$ ) stan wyjątkowy jest unormowany w artykułach: 56, 68, 70 i $81^{19}$ (przy czym konstytucja rozróżnia stan wyjątkowy ogłoszony przez władze centralne w Sarajewie oraz przez władze w Banja Luce). Podczas stanu wyjątkowego może zostać ograniczona część praw człowieka i wolności obywatelskich, z wyjątkiem przewidzianych w artykułach: 10-11, 13-15, 17-20, 24-25 Konstytucji Republiki Serbskiej ${ }^{20}$. Zgodnie z zapisami tejże parlament Bośni i Hercegowiny uchwala ustawy dotyczące organizacji, finansowania, stopni wojskowych, szkolenia, mobilizacji, zaopatrzenia i użycia sił zbrojnych. Parlament ma kompetencję ogłoszenia stanu wojny (w przypadku agresji zbrojnej przeciwko Bośni i Hercegowinie, bezpośredniego zagrożenia wojennego oraz poważnego zagrożenia wojną), jak również ogłoszenia stanu wyjątkowego. 28 listopada 2003 roku Zgromadzenie Narodowe Republiki Serbskiej uchwaliło zmiany (CVI-CXII) do Konstytucji Republiki Serbskiej, które stanowią integralną część konstytucji i weszły w życie z dniem ich ogłoszenia. Wprowadzono do niej m.in. zapisy upoważniające instytucje Bośni i Hercegowiny do ogłaszania stanu wojny, bezpośredniego zagrożenia wojennego i stanu wyjątkowego, pozostawiając instytucjom Republiki Serbskiej prawo ogłaszania na jej terytorium ${ }^{21}$.

Tak więc w obliczu COVID-19 Zgromadzenie Narodowe (parlament) Republiki Serbskiej ogłosił stan wyjątkowy, przekazując prezydentowi uprawnienia legislacyjne $w$ tej sprawie, $w$ celu przyspieszenia uchwalenia przepisów, by złagodzić skutki epidemii. Prezydent Republiki Serbskiej Željka Cvijanović stwierdził:

18 Konstytucja Bośni i Hercegowiny dz. cyt. artykuł V 5. Stały Komitet, s. 338. Zob. też: T.Z. Leszczyński, dz. cyt. s. 47.

19 Ustav Republike Srpske, član 68 (Amandmana XXXII)glasnik Republike Serpske broj 21/92 [on line:] https://www.ilo.org/dyn/natlex/docs/ELECTRONIC/62457/119643/F-532269236/BIH62457\%20Srb.pdf (dostęp: 03.07.2020). 03-07-2020).

20 Ibidem.

21 Ustav Republike Srpske, član 68 (Amandmana XXXII) glasnik Republike Serpske broj 21/92 [on line:] https://www.ilo.org/dyn/natlex/docs/ELECTRONIC/62457/119643/F-532269236/BIH62457\%20Srb.pdf 
Nasze Zgromadzenie Narodowe ogłosiło stan wyjątkowy. Mam nadzieję, że będzie to środek tymczasowy, trwający tygodnie lub miesiące, w zależności od sytuacji zdrowotnej i ogólnej sytuacji ${ }^{22}$.

Rząd podejmuje decyzję o stanie nadzwyczajnym i powoła sztab kryzysowy, tak jak to było podczas powodzi w 2015 r., aby pomóc gospodarce i ludziom ${ }^{23}$.

W przypadku drugiego entitetu, obok Republiki Serbskiej, tworzącego Bośnię i Hercegowinę-Federacji Muzułmańsko-Chorwackiej, Konstytucja (per analogiam jak Konstytucja $\mathrm{BiH}$ ) dosłownie nie stanowi w kwestii stanu wyjątkowego, znajduje się w niej natomiast odniesienie do sytuacji wyjątkowej, z czego jednoznacznie wynika, że gdy zajdzie taka potrzeba, a parlament nie będzie obradował, to wówczas uprawnia się rząd do wydawania dekretów z mocą ustawy. W żadnym razie ustawy te nie mogą jednak naruszać praw i wolności gwarantowanych w Konstytucji (art. 9 Konstytucji Federacji Bośni i Hercegowiny). I właśnie na tej podstawie 17 marca 2020 roku wprowadzono jeden ze stanów nadzwyczajnych, określony mianem stanu katastrofy, który umożliwia przedsięwzięcie nadzwyczajnych środków powstrzymujących rozprzestrzenianie się pandemii COVID-19. Władze Bośni i Hercegowiny ogłosiły taki stan w trosce o możliwość koordynowania wysiłków mających na celu powstrzymanie rozprzestrzeniania się pandemii koronawirusa między dwoma entitetami: Republiką Serbską i Federacją Muzułmańsko-Chorwacką. Od tego momentu nałożono na społeczeństwo wiele restrykcji adekwatnych do stopnia zagrożenia zdrowia i życia. Per analogiam jak w Serbii, zarządzono zamknięcie granic, ograniczono swobodę przemieszczania się, zamknięto przedszkola, szkoły i uczelnie, wprowadzono godzinę policyjna, zabroniono wychodzenia z domów dzieciom poniżej 18 lat i seniorom powyżej 65. roku życia.

22 BiH. Republika Serbska ogłasza stan wyjątkowy w zwiazku z koronawireusem [on line:] https://www.wnp.pl/rynki-zagraniczne/bih-republika-serbskaoglasza-stan-wyjatkowy-w-zwiazku-z-koronawirusem,383028.html (dostęp: 02.07.2020).

23 BiH. Federacja Muzulmańsko-Chorwacka ogłosiła stan katastrofy [on line:] https:// forsal.pl/artykuly/1460764,bih-federacja-muzulmansko-chorwacka-oglosila-stan-katastrofy-w-zwiazku-z-koronawirusem.html (dostęp: 02.07.2020). Zob. też: https://www.klix.ba/vijesti/bih/bosna-i-hercegovina-zbog-koronavirusa-proglasila-vanredno-stanje/200317021 (dostęp: 02.07.2020). 
Ten ostatni z wymienionych zakazów był powodem zaskarżenia decyzji do Sądu Konstytucyjnego Bośni i Hercegowiny. Z dniem 26 marca 2020 roku zarówno Republika Serbska, jak i Federacja Muzułmańsko-Chorwacka złagodziły ograniczenia w swobodzie poruszania się seniorów ${ }^{24}$ i dzieci ${ }^{25}$, które nakazywały tym grupom pozostawanie w domach. Stało się tak po tym, jak Sąd Konstytucyjny Bośni i Hercegowiny 22 kwietnia 2020 roku uznał te obostrzenia, szczególnie dotyczące zakazu wychodzenia z domu, wynikające z wprowadzenia stanu wyjątkowego, za niekonstytucyjne. Co więcej, Sąd Konstytucyjny Bośni i Hercegowiny orzekł, że gwarantowane Konstytucją prawa seniorów i niepełnoletnich, chronione nadto przez Europejską Komisję Praw Człowieka i Podstawowych Wolności, zostały naruszone ${ }^{26}$ (Sochacki, 2015, s. 330). Tak więc decyzja o wprowadzeniu stanu wyjątkowego, pomimo że najczęściej przyświeca jej ważny cel, w tym przypadku ochrona ludności przed śmiertelnym zakażeniem i jej skutkami, generuje jednocześnie poważne problemy natury prawnej. Tak też stało się w opisywanym przykładzie naruszenia praw człowieka w Bośni i Hercegowinie. Warto też zauważyć, że signum specificum Bośni i Hercegowiny jest Statut Dystryktu Brczko, formalnie leżącego w obu częściach składowych Bośni i Hercegowiny (tj. Federacji Bośni i Hercegowiny oraz Republiki Serbskiej), który nie zawiera zapisów dotyczących stanu wyjątkowego ani nie odnosi się do żadnej z konstytucji ww. części administracyjnych kraju. Stanowi natomiast między innymi, że Dystrykt ten posiada własną Policję, która zapewnia bezpieczeństwo i ochronę na jego terenie z poszanowaniem praw i podstawowych wolności gwarantowanych przez Konstytucję Bośni i Hercegowiny, Statut Dystryktu Brczko oraz Europejską Konwencję Praw Człowieka (art. 62 Statutu Dystryktu Brczko) (Bujwid-Kurek, 2010), co w sytuacji nas interesującej jak się

24 Osoby powyżej 65. roku życia będą mogły opuszczać swoje domy w godz. od 9.00-13.00 w poniedziałki, środy i piątki.

25 Dzieci poniżej 18. roku życia będą mogły wychodzić z domu w godz. od 14.00-20.00 we wtorki, czwartki i soboty.

26 Zob. Konstytucja Bośni i Hercegowiny, art. II 2. Standardy międzynarodowe. W: Sz. Sochacki, Bośnia i Hercegowina 1995-2012. Studium politologiczne, Toruń 2015, s. 330. Wcią̇ jeszcze istnieje godzina policyjna w nocy na catym terytorium Bośni i Hercegowiny [on line:] https://twnews.pl/pl-news/bosnia-sad-uznal-obostrzenia-za-niekonstytucyjne (dostęp: 02.07.2020). 
okazuje skutkuje decyzjami adekwatnymi do dwóch entitetówi Bośni i Hercegowiny.

\section{STAN WYJĄTKOWY W MACEDONII PÓENOCNEJ - REAKCJA NA COVID-19}

W kwestii stanów nadzwyczajnych stanowi Konstytucja Macedonii Północnej, poświęcając temu oddzielny rozdział VII. Ochrona Republiki. Stan wojny i stan wyjątkowy. Wyraźnie daje się zauważyć, że zróżnicowano tu dwa stany: stan wojny i stan wyjątkowy. Stan wyjątkowy może być wprowadzony w sytuacji poważnych klęsk żywiołowych lub epidemii, o czym stanowi art. 125 Konstytucji $^{27}$. Konstytucja przewiduje wprowadzenie stanu wyjątkowego na całym obszarze kraju bądź tylko na jego części. Kompetencje w zakresie ogłoszenia stanu wyjątkowego zarezerwowane są dla Sobranija (Parlamentu), który działa na wniosek prezydenta, rządu lub grupy co najmniej 30 deputowanych. Konstytucja wyposaża prezydenta w uprawnienia do wprowadzenia stanu nadzwyczajnego (wojny, wyjątkowego), w sytuacji gdy parlament nie może się zebrać na posiedzeniu. Zobowiązano jednak prezydenta do niezwłocznego przedstawienia parlamentowi do zatwierdzenia tej decyzji, kiedy tylko to będzie możliwe (Wojnicki, 2009, s. 52). Taki właśnie ekstraordynaryjny przypadek zaistniał w marcu 2020 roku (zagrożenia COVID-19), kiedy to Parlament został rozwiązany w lutym 2020 roku, z powodu fiaska starań ówczesnego premiera rządu Zorana Zaewa, który 3 stycznia 2020 roku podał się do dymisji, przekazując na okres trzech miesięcy władzę rządowi technicznemu, na czele którego stanął Oliver Spasovski (ówczesny minister obrony spraw wewnętrznych). W takiej sytuacji decyzję o ogłoszenie stanu wyjątkowego podjął prezydent państwa. Obecnie prezydentem Macedonii Północnej jest Stewo Pendarowski, w gestii którego leżało podjęcie tej ważnej i jakże odpowiedzialnej decyzji, zważywszy na mające się odbyć przedterminowe wybory parlamentarne zaplanowane według kalendarza wyborczego

27 Устав на Република Северна Македонија [on line:] https://www.sobranie. mk/ustav-na-rm.nspx (dostęp: 03.07.2020). 
na 12 kwietnia 2020 roku $^{28}$. Już 21 marca, tj. na trzy tygodnie przed planowanym terminem, ogłoszono że wybory parlamentarne nie dojdą do skutku. Na specjalnym posiedzeniu przyjęto dekret mający moc prawną "zawieszający wszystkie działania wyborcze i wszystkie prace związane z procesem wyborczym" 29 .

Rząd podjął takie działania, które były wynikiem wcale niełatwego konsensusu wypracowanego przez koalicje partyjne i partie polityczne Macedonii Północnej: koalicję SDSM (Socjaldemokratyczny Związek Macedonii) i albański Ruch Besa, Demokratyczny Związek na rzecz Integracji (DUI), VMRO-DPMN (Wewnętrzna Macedońska Opozycja Rewolucyjna-Demokratyczna Partia Macedońskiej Jedności Narodowej) (konserwatywna koalicja opozycyjna). Koalicję wyborczą udało się też utworzyć ruchowi noszącemu nazwę „Nigdy Północna, Zawsze Macedonia” ${ }^{30}$, która sprzeciwiała się zawartej przez rząd Zorana Zaewa umowie z Grecją, na mocy której doszło w lutym 2019 roku do zmiany nazwy państwa. Podejmując decyzję o przesunięciu wyborów parlamentarnych za niezbędne uznano znalezienie podstawy prawnej ją uzasadniającą. Ta kwestia była zauważona przez przewodniczącego Parlamentu Talata Xhaferiego, który zwrócił uwagę na fakt, że problematyczne jest przełożenie daty wyborów, w sytuacji gdy parlament został już rozwiązany. Poddając w wątpliwość tę decyzję, wskazywał na problem natury

28 Zgodnie $\mathrm{z}$ kalendarzem wyborczym wybór parlamentarne powinny być zorganizowane jesienią $2020 \mathrm{r}$. Jednak decyzję o przyspieszonych wyborach podjął jeszcze w październiku 2019 r. premier rządu Macedonii Północnej Zoran Zaew w odpowiedzi na brak zgody Rady Europejskiej na rozpoczęcie negocjacji z Macedonią Północną. Pamiętajmy, że kwestia integracji europejskiej była kwestia ambicjonalną prowadzonej przez niego polityki. Więcej zob. Macedonia Pólnocna: przesunięcie terminu wyborów w cieniu koronawirusa [on line:] https://ies.lublin.pl/komentarze/macedonia-polnocna-przesuniecie-terminu-wyborow-w-cieniu-koronawirusa-141-44-2020 (dostęp: 03.07.2020).

29 Wybory prezydenckie 2020. Na świecie przenosi się wybory, ale nie wszędzie [on line:] https://wiadomosci.onet.pl/swiat/wybory-prezydenckie-2020-na-swiecie-przenosi-sie-wybory-ale-nie-wszedzie/66w5cgw (dostęp; 03.07.2020).

30 Tym hasłem posługują się podczas protestów antyrządowych. Hasło to wykorzystywane jest też przez macedońskich kibiców sportowych. Zob. Macedonia Pótnocna: przesunięcie terminu wyborów w cieniu koronawirusa [on line:] https://ies.lublin.pl/komentarze/macedonia-polnocna-przesuniecie-terminu-wyborow-w-cieniu-koronawirusa-141-44-2020 (dostęp: 03.07.2020). 
prawno-konstytucyjnej, który w jego opinii należy jak najprędzej wyjaśnić ${ }^{31}$. 16 marca 2020 roku w związku z pierwszymi zachorowaniami na COVID-19 w miejscowościach Debar i Centar Župa, Prezydent zwołał posiedzenie Rady Bezpieczeństwa Narodowego, która zajęła się oceną sytuacji w kraju w związku z zagrożeniem epidemią. Już wtedy nie wykluczono, że z powodu pandemii nie odbędą się w zaplanowanym terminie wybory parlamentarne. Prezydent oznajmił: „Nie będzie końca świata, jeśli je odłożymy" ${ }^{32}$. Decyzję o stanie wyjątkowym uzasadnił też m.in. i tym, że

stan wyjątkowy nie jest związany z liczbą zarażonych i zmarłych, ale został wprowadzony, aby umożliwić rządowi podjęcie natychmiastowych działań zdrowotnych, społecznych i gospodarczych ${ }^{33}$.

Najpierw, 16 marca 2020 roku ogłoszono stan wyjątkowy tylko w tych dwóch miejscowościach, uznając je za główne ognisko infekcji i zastosowano zakaz opuszczania oraz odwiedzania tych miejscowości, a następnie, dwa dni później, stan wyjątkowy ogłoszony został już na terytorium całego kraju. Decyzja ta uprawniła rząd do przyjmowania rozporządzeń z mocą ustawy. Wprowadzono stan wyjątkowy na okres 30 dni, który w sytuacji tego wymagającej może zostać przedłużony. Od 8 kwietnia 2020 roku wprowadzono nadzwyczajne środki, m.in.: zamknięto granice państwa, odwołano wybory parlamentarne zaplanowane na 12 kwietnia (Wielkanoc), wprowadzono godzinę policyjna, osobom powyżej 65. roku życia także dzieciom poniżej 18 lat zabroniono wychodzenia $z$ domu, wprowadzono zakaz zgromadzeń, zamknięte zostały żłobki, przedszkola, szkoły i uczelnie, zamknięto lotniska międzynarodowe w Skopje i Ochrydzie. Wobec gmin Debar i Centar Župa zastosowano szczególny środek - kwarantannę $e^{34}$. Jednak 12 czerwca 2020 roku Prezydent zniósł przedłużany stan wyjątkowy, tym samym stwarzając możliwość prawną przeprowadzenia wyborów

31 Ibidem.

32 Macedonia Pótnocna: stan wyjątkowy w dwóch miejscowościach z powodu koronawirusa [on line:] https://forsal.pl/artykuly/1459959,macedonia-pln-stan-wyjatkowy-w-dwoch-miejscowosciach-z-powodu-koronawirusa.html (dostęp: 03.07.2020).

33 Ibidem.

34 Ibidem. 
parlamentarnych, które wyznaczono na 15 lipca 2020 roku. W opinii wyrażonej przez Prezydenta, związanego z Socjaldemokratycznym Związkiem Macedonii, tkwiło przeświadczenie, że: „,Przeprowadzenie wyborów jest kluczowe dla rozwoju państwa. Wybory w czasie pandemii, która potrwa jeszcze długo, są konieczne, aby mieć sprawnie funkcjonujący parlament i legalnie powołany rząd" ${ }^{\prime 35}$.

Tak więc i tym razem, podobnie jak w przypadku Serbii, ,interes polityczny” wziął górę nad „rozsądkiem ludzkim” - dbanie o zdrowie obywateli państwa. O ile politologicznie „interes polityczny” daje się usprawiedliwić, to o wiele trudniej jest znaleźć racjonalne uzasadnienie dla braku „rozsądku ludzkiego" (czytaj: zdrowie i bezpieczeństwo) obywateli.

\section{STAN WYJĄTKOWY W KOSOWIE - REAKCJA NA COVID-19}

Na pierwsze zachorowania na COVID-19 zareagowały także władze Kosowa, które relatywnie szybko, sięgając po stosowny po temu instrument konstytucyjny ${ }^{36}$, ogłosiły na obszarze całego kraju stan wyjątkowy (art. 131 Konstytucji Kosowa):

1. Prezydent Republiki Kosowa może ogłosić Stan Wyjątkowy, gdy:

1) istnieje potrzeba wprowadzenia wyjątkowych środków obrony;

2) istnieje wewnętrzne zagrożenie porządku konstytucyjnego lub bezpieczeństwa publicznego; lub

3) w przypadku klęski żywiołowej na całym lub części terytorium Republiki Kosowa (...) (Nowak, 2010, s. 113).

4) Jeśli istnieje zagrożenie dla porządku konstytucyjnego lub bezpieczeństwa publicznego Republiki Kosowa, lub wystąpiła klęska żywiołowa na części lub na całym terytorium Republiki Kosowa, Prezydent Republiki Kosowa ogłasza Stan Wyjątkowy

35 Ibidem. Więcej na temat, zob. Macedonia Pótnocna: przesunięcie terminu wyborów w cieniu koronawirusa [online:]https://ies.lublin.pl/komentarze/macedonia-polnocna-przesuniecie-terminu-wyborow-w-cieniu-koronawirusa-141-44-2020 (dostęp: 03.07.2020).

36 Ustav Republike Kosovo O(sa amandmanima I -XXIV) član 131 [online:] http://biblioteka.sejm.gov.pl/wp-content/uploads/2017/05/Kosowo_ serb_010117.pdf (dostęp: 04.07.2020). 
po konsultacji z Premierem. Po ogłoszeniu Stanu Wyjątkowego Prezydent natychmiast wydaje dekret, w którym określa naturę zagrożenia i ograniczenia praw i wolności (Nowak, 210, s. 113 i 114).

Prezydent Kosowa Hashim Thaci i premier Aljbin Kurtija nie wyrażali wspólnego stanowiska co do ogłoszenia stanu wyjątkowego z powodu zachorowań na COVID-19. Konsekwencją braku porozumienia $\mathrm{w}$ tej kwestii było nawet odwołanie rządu. Prezydent zdecydowanie optował za ogłoszeniem stanu wyjątkowego, zgoła innego zdania był premier rządu, który twierdził, że: „Instytucje, takie jak szpitale, policja, są bardzo dobrze zorganizowane i zarządzane oraz mają pełną kontrolę nad sytuacją epidemiologiczną" ${ }^{37}$.

W opinii doradców premiera (m.in. Erzen Vranić) ${ }^{38}$ tkwiło przekonanie, że po działania kryzysowe będzie można sięgać w momencie, gdy wszystkie inne możliwości zostaną wyczerpane. Jak już zostało wcześniej zauważone, zgodnie z Konstytucją Republiki Kosowa ogłoszenie stanu wyjątkowego jest zarezerwowane dla kompetencji Prezydenta i zatwierdzane przez Kuventi (parlament), w którym większość mają partie polityczne popierające rząd. Jednak, co warto podkreślić, od 25 marca 2020 roku już takiej większości nie mają. Powodem dyferencjacji partii politycznych było wyrażenie odmiennych stanowisk co do ogłoszenia stanu wyjątkowego. W wyniku sporu premier A. Kurtija, stojący na czele centrolewicowej partii Samooreślenie, odwołał ministra spraw wewnętrznych Agima Veliu (reprezentującego w rządzie partię prawicową - Demokratyczną Ligę Kosowa (LDK)), który w tym sporze zajął stronę prezydenta. Sprzeciwiająca się ogłoszeniu stanu wyjątkowego była też partia polityczna skupiająca mniejszość serbską w Kosowie - Tymczasowa Srpska Lista, która swoje niechętne stanowisko motywowała poważną obawą przed wysłaniem wojska do zamieszkałej w większości przez Serbów północnej części kraju. W wydanym przez tę partię komunikacie prasowym wyrażono następującą opinię:

37 Kosowo: Rząd odwołany w zwiazki z pandemia koronawirusa [on line:] https:// www.euractiv.pl/section/polityka-zagraniczna-ue/news/kosowo-serbia-balkany-nato-unia-europejska-hoti-kryzys-celny-wojna-na-balkanach/ (dostęp:04.07.2020).

Ibidem. 
Prisztina próbuje rozmieścić siły zbrojne w północnym Kosowie pod pretekstem ochrony obywateli, podczas gdy prawdziwym celem jest okupacja serbskich gmin ${ }^{39}$.

W związku z zaistniałą sytuacją LDK wyszła z koalicji partyjnej i złożyła wniosek o wotum nieufności wobec premiera ${ }^{40}$. W wyniku głosowania wniosku w Parlamencie rząd został odwołany. A. Kurtija wciąż jeszcze pełni funkcje premiera, bowiem Kosowo znajduje się w trudnej epidemiologicznej sytuacji, która uniemożliwia przeprowadzenie przedterminowych wyborów.

18 marca 2020 roku z powodu COVID-19 na obszarze całego kraju ogłoszono stan wyjątkowy. Po potwierdzeniu w połowie marca tegoż roku pierwszych zachorowań zamknięto przedszkola, szkoły, uczelnie i zakazano zgromadzeń, zawieszono też połączenia lotnicze z Włochami i kilkoma państwami Unii Europejskiej, zamknięto granice. Dla przyjeżdżających do kraju z zagranicy wprowadzono obowiązek czternastodniowej kwarantanny ${ }^{41}$. W chwili obecnej (lipiec 2020) stopniowo odchodzi się od wprowadzonych restrykcji, którymi dotknięta została ludność Kosowa, w związku z czym istnieje też realna szansa na przeprowadzenie przedterminowych wyborów parlamentarnych, których termin jeszcze nie został wyznaczony.

\section{PODSUMOWANIE}

Naczelnym celem badawczym przeprowadzonych rozważań było zwrócenie uwagi na te państwa pojugosłowiańskie, które - stojąc w obliczu zagrażającej zdrowiu i życiu ludności, pandemii COVID-19 - skorzystały z możliwości ogłoszenia stanu wyjątkowego gwarantowanego nadrzędnym aktem prawnym (Konstytucją).

\section{Ibidem.}

40 Za odwołaniem rządu zagłosowało 82 ze 120 deputowanych, w związku z tym wniosek otrzymał wymaganą większość do odwołania rządu. Zob. więcej: ibidem.

41 Ibidem. Zob. też: Vlada Kosova proglasila vanredno stanje u javnom zdravstvu zbog korona virusa [on line:] https://www.aa.com.tr/ba/balkan/vlada-kosova-proglasila-vanredno-stanje-u-javnom-zdravstvu-zbog-korona-virusa/1767190(dostęp: 04.07.2020).. 
Ustalono, że w związku z pandemią COVID-19 cztery spośród siedmiu państw pojugosłowiańskich: Serbia, Bośnia i Hercegowina, Macedonia Północna oraz Kosowo na całym terytorium swych państw ogłosiły stan wyjątkowy. Warto zauważyć, iż w Serbii i Macedonii Północnej mające się odbyć wybory parlamentarne zostały przesunięte. W Kosowie, gdzie wprowadzono stan wyjątkowy, po rozwiązaniu parlamentu wciąż oczekuje się na wyznaczenie daty przedterminowych wyborów. Namysł politologiczny pozwala pozytywnie zaopiniować decyzje o przesunięciu wyborów parlamentarnych w obliczu śmiertelnego wirusa COVID-19. Autorka podziela także opinie tych wszystkich, którzy są zwolennikami ogłoszenia stanu wyjątkowego w przypadku zmierzania się z tą pandemią. W tym miejscu niech mi wolno na dygresję - usprawiedliwieniem dla decydentów państw wzbraniających się przed uruchomieniem jednego z mechanizmów zarządzania kryzysowego zapewne jest konieczność wypłacania rekompensaty za poniesione szkody na skutek wprowadzenia ograniczeń na czas wprowadzenia stanu wyjątkowego. Państwa takie jak Bośnia i Hercegowina, Macedonia Północna oraz Kosowo mogą liczyć na pomoc finansową w postaci pożyczek na bardzo korzystnych warunkach, o czym zdecydowała Rada Europejska 5 maja 2020 roku. Pomoc ze strony Unii Europejskiej dotyczy państw partnerskich, które są objęte politykami rozszerzenia i sąsiedztwa, i posłuży na pokrycie bezpośrednich potrzeb finansowych, znacznie zwiększonych w wyniku pandemii. Wraz ze wsparciem ze strony Międzynarodowego Funduszu Walutowego, przekazane środki będą pomocne we wzmocnieniu stabilności makrogospodarczej, zapewne ułatwią swobodniejsze dysponowanie zasobami, tak by chronić obywateli i łagodzić skutki społeczno-gospodarcze COVID-1942. O tym, że decyzja o ogłoszeniu stanu wyjątkowego w reakcji na pandemię nie należy do łatwych, szczególnie decydowanie o przesunięciu daty wyborów parlamentarnych, świadczą toczone spory polityczne (Serbia, Kosowo), które nierzadko kończą się rozwiązaniem parlamentu

42 Bośnia i Hercegowina otrzyma $250 \mathrm{mln}$ euro, Macedonia Pólnocna 160 $\mathrm{mln}$ i Kosowo $100 \mathrm{mln}$ euro. Niestety taka pomoc nie jest przewidziana dla Serbii, zob. Covid-19: Rada zatwierdza 3 mld EUR pomocy dla państw partnerskich [on line:] https://www.consilium.europa.eu/pl/press/press-releases/2020/05/05/covid-19-council-greenlights-3-billion-assistance-package-to-support-neighbouring-countries/ (dostęp: 04.07.2020). 
(Macedonia Północna). Jak wynika z przeprowadzonych rozważań stan wyjątkowy, z racji swej specyfiki, generuje szereg obostrzeń, które najczęściej wywołują niezadowolenie i protesty społeczne (Bośnia i Hercegowina). Po to rozwiązanie - ogłoszenie stanu wyjątkowego - sięgać należy więc niezwykle roztropnie, każdorazowo mając na względzie poszanowanie praw i wolności człowieka.

\section{BibLIOGRAFIA}

Brown, J. (2018). Grypa. Sto lat walki. Tłum. J. Gilewicz. Kraków: Wydawnictwo Uniwersytetu Jagiellońskiego.

Bujwid-Kurek, E. (2010) Dystryk Brczko Bośni i Hercegowiny jako gwarant pokoju i bezpieczeństwa na Bałkanach Zachodnich. W: K. Budzowski (red.), Europejska polityka bezpieczeństwa i integracji (211-223). Kraków: Wydawnictwo Akademii Frycza Modrzewskiego.

Bujwid-Kurek, E. (2012). Serbia w nowej przestrzeni ustrojowej. Dzieje, ustrój, konstytucja. Kraków: Księgarnia Akademicka.

Bujwid-Kurek, E. (2012). Stany nadzwyczajne w zapisach konstytucji wybranych państw Europy Środkowo-Wschodniej [w:] W. Bernacki i A. Walaszek (red.), Amerykomania. Księga jubileuszowa ofiarowana profesorowi Andrzejowi Mani, t. 2 (111-127). Kraków: Wydawnictwo Uniwersytetu Jagiellońskiego.

Cartwright, F.F., Biddiss, M. (2002). Niewidoczny wróg. Zarazy $i$ historia. Przekł. M. Wyrwas-Wiśniewska. Warszawa: Wydawnictwo Wołoszański.

Kiple, K.F. (2002) (red.). Wielkie epidemie w dziejach ludzkości. Przekł. Z. Sidorkiewicz. Poznań: Oficyna Wydawnicza Atena.

Konstytucja Bośni i Hercegowiny, art. II 2. Standardy międzynarodowe. (2015). W: Sz. Sochacki, Bośnia i Hercegowina 1995-2012 (330). Studium politologiczne. Toruń: Wydawnictwo Adam Marszałek.

Konstytucja Republiki Kosowa. (2010). Wstęp i tłum. K. Nowak. Rzeszów: Wydawnictwo Uniwersytetu Rzeszowskiego.

Leksykon prawniczy. (1997). U. Kalina- Prasznic (red.). Wrocław: Atla2.

Leszczyński, T.Z. (2011). Konstytucyjne podstawy stanów nadzwyczajnych w państwach bałkańskich i w Turcji. Kraków Krakowskie Towarzystwo Edukacyjne sp. z o.o. - Oficyna Wydawnicza AFM.

Mała encyklopedia wiedzy politycznej. (2001). M. Chmaj, W. Sokół (red.). Toruń: Wydawnictwo Adam Marszałek.

Skrzydło, W. (2002). Konstytucja Rzeczpospolitej Polskiej. Komentarz. Kraków:Zakamycze. 
Wojnicki, J. (2009). System konstytucyjny Macedonii. Warszawa: Wydawnictwo Sejmowe.

\section{Netografia}

Ustav Republike Kosovo (sa amandmanima I-XXIV) član 131 [on line:] http://biblioteka.sejm.gov.pl/wp-content/uploads/2017/05/Kosowo_ serb_010117.pdf (dostęp:04.07.2020).

https://www.consilium.europa.eu/pl/press/press-releases/2020/05/05/ covid-19-council-greenlights-3-billion-assistance-package-to-support-neighbouring-countries/(dostęp: 04.07.2020).

https://ies.lublin.pl/komentarze/macedonia-polnocna-przesuniecie-terminu-wyborow-w-cieniu-koronawirusa-141-44-2020 (dostęp: 03.07.2020).

Vlada Kosova proglasila vanredno stanje u javnom zdravstvu zbog korona virusa [on line:] https://www.aa.com.tr/ba/balkan/vlada-kosova-proglasila-vanredno-stanje-u-javnom-zdravstvu-zbog-korona-virusa/1767190 (dostęp: 04.07.2020).

Kosowo: Rzad odwołany w zwiazki z pandemia koronawirusa [on line:] https:// www.euractiv.pl/section/polityka-zagraniczna-ue/news/kosowo-serbia-balkany-nato-unia-europejska-hoti-kryzys-celny-wojna-na-balkanach/ (dostęp: 04.07.2020).

Macedonia Pótnocna: stan wyjątkowy w dwóch miejscowościach z powodu koronawirusa [online:] https://forsal.pl/artykuly/1459959,macedonia -pln-stan-wyjatkowy-w-dwoch-miejscowosciach-z-powodu-koronawirusa.html (dostęp: 03.07.2020).

Ustav Republike Srpske, član 68 (Amandmana XXXII) glasnik Republike Serpske broj 21/92 [on line:] https://www.ilo.org/dyn/natlex/docs/ ELECTRONIC/62457/119643/F-532269236/BIH62457\%20Srb.pdf

BiH: Republika Serbska ogłasza stan wyjatkowy w zwiazku z koronawirusem [on line:] https://www.wnp.pl/rynki-zagraniczne/bih-republika-serbska-oglasza-stan-wyjatkowy-w-zwiazku-z-koronawirusem,383028. html (dostęp: 02.07.2020).

BiH: Federacja Muzutmańsko-Chorwacka ogłosił stan katastrofy [on line:] https://forsal.pl/artykuly/1460764,bih-federacja-muzulmansko-chorwacka-oglosila-stan-katastrofy-w-zwiazku-z-koronawirusem. html (dostęp: 02.07.2020). Zob. też: https://www.klix.ba/vijesti/bih/ bosna-i-hercegovina-zbog-koronavirusa-proglasila-vanredno-stanje/200317021 (dostęp: 02.07.2020).

U Srbiji je jutros završen poslednij policijski čas: poštujte mere koje su i dalje na snazi [on line:] https://www.telegraf.rs/vesti/srbija/3186771-u-srbiji-je-jutros-zavrsen-poslednji-policijski-cas-pos (dostęp: 01.07.2020). 
Historyczne spory stana na drodze Macedonii Ptn. do UE? [on line:] https:// www.euractiv.pl/section/polityka-wewnetrzna-ue/news/unia-europejska-bulgaria-macedonia-polnocna-rozmowy-akcesyjne-koronawirus-kryzys/ (dostęp: 03.07.2020).

Ustav Republike Srpske, član 68 (Amandmana XXXII) glasnik Republike Serpske broj 21/92 [on line:] https://www.ilo.org/dyn/natlex/ docs/ELECTRONIC/62457/119643/F-532269236/BIH62457\%20Srb.pdf (dostęp: 03.07.2020).

Serbia wprowadza stan wyjatkowy w zwiazku z pandemia [on line:] https:// www.defence24.pl/serbia-wprowadza-stan-wyjatkowy-w-zwiazku-z-epidemia-koronawirusa (dostęp: 01.07.2020).

Wybory prezydenckie 2020. Na świecie przenosi się wybory, ale nie wszędzie [on line:] https://wiadomosci.onet.pl/swiat/wybory-prezydenckie-2020-na-swiecie-przenosi-sie-wybory-ale-nie-wszedzie/66w5cgw (dostęp: 03.07.2020).

Izbori u Srbiji 2020, Kosovo, korona i UE: šta sve čeka novu Vladu i parlament [on line:] https://www.bbc.com/serbian/lat/srbija-53095067 (dostęp: 04.07.2020).

Protest sa zahtevom odlaganja izbora, kolona demonstranata ispred RTS [on line:] http://rs.n1info.com/Vesti/a597737/Protest-protiv-vlasti-na-Trgu-Republike.html (dostęp: 01.07.2020).

Akcija "Bukom protiv diktature" $i$ 13. Veče zaredom u više gradova u Srbije [on line:] http://rs.n1info.com/Vesti/a597535/Akcija-Bukom-protiv -diktature-i-13.-vece-zaredom-u-vise-gradova-u-Srbiji.html (dostęp: 01.07.2020).

Brnabić, A. S izborima nema licitirnja, moramo da vratimo mandate građanima [on line:] http://rs.n1info.com/Izbori-2020/a596755/Brnabic-S-izborima-nema-licitiranja-moramo-da-vratimo-mandate-gradjanima.html (dostęp: 02.07.2020).

Prezydent Serbii zapowiada odwołanie stanu wyjątkowego [on line:] https://www.tvp.info/47863787/prezydent-serbii-zapowiada-odwolanie-stanu-wyjatkowego (dostęp: 01.07.2020).

Što po Ustavu Srbije podrozumeva uvođenje vanrednog stanja? [on line:] https://www.danas.rs/drustvo/sta-po-ustavu-srbije-podrazumeva-uvodjenje-vanrednog-stanja/ (dostęp: 04.07.2020).

Korona virus i vanredno stanje u Srbiji: Šta to znači i koje mere su uvedene [on line:] https://www.bbc.com/serbian/lat/srbija-51905122 (dostęp: 02.07.2020).

Koronawirus: Które kraje wprowadzity stan wyjątkowy w Europie? [on line:] https://www.euractiv.pl/section/bezpieczenstwo-i-obrona/news/ koronawirus-ktore-kraje-wprowadzily-stan-wyjatkowy/ (dostęp: 01.07.2020). 
Chan, M. World Now at the Start of 2009 Influenza Pandemic. World Health Organization [on line:] http://www.who.int/mediacentre/news/ statements/2009/h1n1_pandemic_phase6_20090611/en/ (dostęp: 11.06.2020).

World Health Organization, Middle East Respiratory Syndrome Coronavirus (MERS-CoV). Summary of Current Situation, Literature Upade and Risk Assessment, 7 lipca 2015 [on line:] http://apps.who. int.iris.bitstream/10665/179184/WHO_MERS_RA_15.1_eng.pdf (dostęp: 10.06.2020).

\section{Copyright and License}

This article is published under the terms of the Creative Commons Attribution - NoDerivs (CC BY- ND 4.0) License http://creativecommons.org/licenses/by-nd/4.0/ 